\title{
Research on the Veblen Effect and Marketing Strategy of China's Sports Market
}

\author{
Zhong WU ${ }^{1,{ }^{*}}$ and Xiao-qian LIU ${ }^{1}$ \\ ${ }^{1}$ Wuhan Business University, Dongfeng Avenue NO.816, Wuhan Economic and \\ Technological Development Zone, Wuhan, Hubei, China \\ ${ }^{\star}$ E-mail:7849800@qq.com
}

Keywords: Veblen effect, China's sports market, Sports luxuries.

\begin{abstract}
In order to study the Veblen effect of china's sports market and solve the problem of marketing of sports luxuries, law of demand and Veblen conspicuous consumption theory are applied to explain the price of conspicuous consumption and positive relevant disciplines of its demand and analyze the Veblen effect of China's sports market so as to establish preferences factor model of sports luxuries consumption in china and propose the marketing strategy of sports luxuries. Firstly to analyze the demanding curve of conspicuous commodity and different display of demanding curve of general commodities; then by analyzing the sports luxuries market in china and establishing factor model based on the social-oriented factor, self-orientation factor and commodity brand orientation factor; and finally presents a series of marketing strategy involving in popularizing professional knowledge, utilizing high price, establishing emotional bond and expanding high-end costumed group.
\end{abstract}

\section{Introduction}

With the development of social progress and sports economy in china, people's outlook on value and way of consumption and leisurely life are changing. With the continuous increase of national economy, people's income is increasing and most of the consumers like to change the enjoyment to the quality of life and health due to driven by the preference of consumption and also to buy more high level commodities. Presently china's sports commodities have accessed to an important and high speed development era and people's demanding structure is involving in the demanding of sports products and people like to participate in the sports activities and purchase the sports products and to watch the sports competitions and all these become one of the enjoyable consumption among those and sports luxuries becomes an essential components.

Now, consumers' demand of sports luxuries is escalating and buy high price sports luxuries to meet ones emotional appeals and to show the personality taste and achieve the self-recognition compared with the western sports luxuries [1], Chinese consumers attach important to conspicuous value of luxuries, even the consumers with less purchasing power are willing to spend more money on luxuries and this causes the market of conspicuous consumption more active and dynamic [2]. Under this background, more and more limit edition(such as Jordan 23 issued by Nike)which with elite special design and more memorable sports luxuries, such kinds of limited edition is emerging in the market and deeply loved and envied by the consumers [3].

Even so, domestic and overseas experts and scholars are mainly focusing on the study of the concept, culture [4], production, consumption [5] and management of luxuries [6,7], they do 
not combine the conspicuous consumption theory of Veblen and the sports luxuries analysis together, and they do not analyze the policy which will affect the luxuries. This paper takes the conspicuous consumption theory of Veblen as a basis and carries out Veblen effect study so as to establish preference factor model and proposal china's sports luxuries marketing strategy.

\section{Demanding Curve of Conspicuous Commodities}

The law of demand in economy shows that when the conditions are not changed (non price factor of decisive demand), the relation of the price of one commodity and its demands is negatively related. Please refer to the following Fig. 1, when the commodity price drops from $\mathrm{P} 1$ to $\mathrm{P} 2$, the demand is increasing from $\mathrm{Q} 1$ to $\mathrm{Q} 2$, namely point a moves to $\mathrm{b}$ along with the curve. Therefore, in reality that not all the commodities follows the law of demand, American economist Veblen made a research that the purchaser for a certain commodities is not for use purpose but to show off, such kinds of commodities do not present the above mentioned negative relevant relation, but with the principle of high price with more demand and shows positive relevant discipline, this is the Veblen effect in economy, and this commodities also called conspicuous commodities. Refers to the Fig. 2, when the commodities price rises from $\mathrm{P} 1$ to $\mathrm{P} 2$, the demand is increasing from $\mathrm{Q} 1$ to $\mathrm{Q} 2$, namely a point is moving to $\mathrm{b}$ along with the curve.

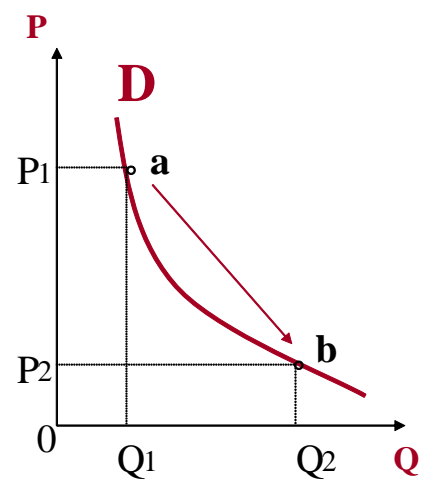

Figure 1. General commodities demand curve

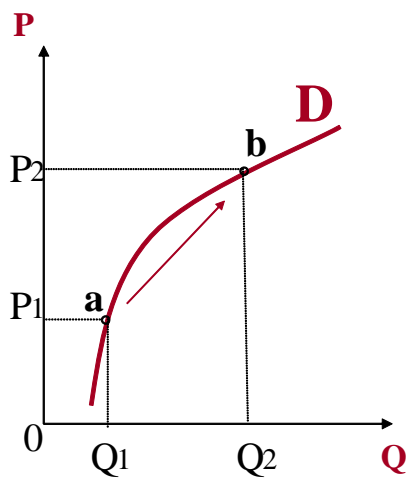

Figure 2. Conspicuous commodities demand curve

\section{Veblen Effect in China's Sports Market}

\section{Sports Luxuries Market Analysis in China}

With the rapid development of china's economy, the GDP keep momentous and stable increase and the national material wealth is increasing and the conspicuous value of sports commodities is just catering some people's pursuit mentality and causing the debut of the sports luxuries.

According to the Bane investigation and statistic that china's luxuries market keep increasing since 2008 and continues with rapid increasing growth even the global market is downward. Now Chinese consumers become the global luxuries consumption group and account for the $25 \%$ of world luxuries consumption rate. At the same time, due to the limit edition of commodities which stimulate the consumption desire of consumers and gain a lots of profits. in the year 2008 Olympic game there are a limited edition clothes by Adidas franchise 
in Hangzhou stores attract great attention, there are 2008 clothes issued in china and with the price 2008RMB and for this shop only several clothes and sell out once put on the counter.

The category of sport luxuries consumer mainly includes two rich groups, i.e. one is the group who likes to show off and the other is craving for luxuries.

Table 1. Segmental group of china's rich consumers

\begin{tabular}{|c|c|c|l|}
\hline type & $\begin{array}{c}\text { average family } \\
\text { yearly income }\end{array}$ & $\begin{array}{c}\text { property } \\
\text { ratio }\end{array}$ & \multicolumn{1}{c|}{ main features } \\
\hline $\begin{array}{c}\text { conspicuous } \\
\text { type }\end{array}$ & 78,000 & $22 \%$ & $\begin{array}{l}\text { Income is slightly higher than the average level, } \\
\text { more people live in the biggest first-tier city and } \\
\text { are willing to spend money on luxuries and like to } \\
\text { show off and pay attention to the brand and like } \\
\text { to compare the commodities and raise the } \\
\text { confidence of his financial status. }\end{array}$ \\
\hline $\begin{array}{c}\text { luxuries } \\
\text { craving type }\end{array}$ & 69,000 & $11 \%$ & $\begin{array}{l}\text { Compared with the rich level, most of people live } \\
\text { in the second-tier cities are craving for the } \\
\text { luxuries and the purchase capacity exceeds his } \\
\text { economy and they like to show off and have their } \\
\text { own favourable brands. }\end{array}$ \\
\hline
\end{tabular}

No matter what type of consumers is, vanity or craving for luxuries, all embodies the Veblen effect and they consist the main consumption group of the sports luxuries markets. In addition, the social pillar of young generation, due to their personal pursuit and the show-off which becomes a motivation for pursuit luxuries. Except of famous watches, leather bags, cars and perfumes industries, the sports luxuries market also provide various services to the consumers such as signature of popular stars also becomes a highlight of sports luxuries market.

\section{Preference Effect Factor Model of Sports Luxuries Consumption}

By analyzing the consumption features, this paper designs the preference effect factor model of sports luxuries consumption, refers to the following Fig. 3.

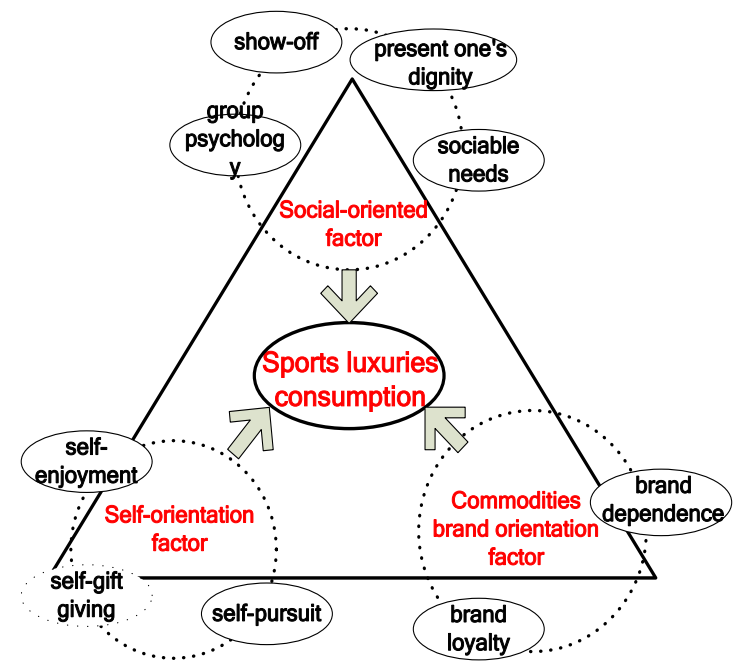

Figure 3. Preference effect factor model of sports luxuries consumption in China 
The above preference effect factor includes social-oriented factor, self-orientation factor and commodities brand orientation factor, details are as follows.

Social-oriented Factor. Social-oriented factor refers to the consumer preference factors due to social effects which including show-off, and present one's dignity, group psychology, identity and sociable needs.

The motivation of consumers for the conspicuous commodities lies in the pursuit of conspicuous commodities, when the purchaser become more and the this value will become low on the contrary, so only the price is increasing can raise the value of commodities and the Veblen effect can be displayed. To buy the sports luxuries is the way to define and confirm the social position of the consumer and the symbol of social dignity and identity which reflects their high salary, culture pursuit and psychological features.

Group psychology is the main reason for arbitrary consumption. When one sports luxury advertised on one consumer or star which the value of the luxuries will be excellently displayed and published, the consumer will buy the same luxuries as the star and more and more people will consume and leads to the best selling of sports luxuries.

For those social elite, they have better education and salary with substantial high-level consumption and taste; they are pursuing modern way of life. So they are easier to recognise the brand quality and the luxuries symbol so as to meet one's needs in the sociality.

Self-orientation Factor. Self-orientation factor is the factor caused by the consumers, including self-pursuit, self-enjoyment and self-gift giving.

As for the sports luxuries consumers, world famous sports brand is the necessity of high-level life, such as Adidas presents a high quality and taste, it will attract people's attention while wearing a pair of Adidas shoes, it shows the high dignity of oneself and also make them more confidence and reach the target of self-enjoyment. Self-gift giving is a symbolic self-communication due to a special indulgence; this behavior is normally well-planned and is related to some background. Simply speaking it is self-gift giving. Such as some well-off second generation, they are crazy for some sports stars and buy some high price sports clothes and shoes which the stars name signed on, so that to meet their satisfaction.

Commodities Brand Orientation Factor. Commodities brand orientation factor refers to the commodities itself which affect the consumer's preference, including brand loyalty and dependence.

The products produced by the world famous luxuries brand company always symbolize the advanced technology, superior quality and good after service, and these can make the consumers happy, so the consumers do not pay attention to the price but enjoy the quality and service of the commodities and they will rely on the sports brand and be loyal to the brand. With the long history of culture and advanced fashionable elements enable the consumers to rely on the brand. Such as the craziness for the purchase of Jordan 11, the purpose of this product is to call Jordan back to the basketball playground, Jordan wears these clothes and wins the champion for the bull team and it is meaningful and memorable in the heart of fans. And Jordan 11 series is a trans-century product; Jordan 11 is the only shoes made of patent leather. Before selling, someone pre-selling with the price of 1600RMB, a lot of people book the shoes form the bulletin board and some people pre-sale at the price of 6000RMB. So brand loyalty and dependence also can stimulate consumers' preference on sports luxuries.

\section{Marketing Difficulty Analysis of China's Sports Luxuries}

Now, china's sports undertakings attract more attention, people attach more importance to the sports commodities, the proportion ratio of sports luxuries accounts less rate in china 
presently, and most of the consumers lack of history and culture knowledge of luxuries. For example, as the famous brand NIKE, more people know this brand, but know nothing about the NIKE culture and classic product; however it is not realistic for them to buy the sports luxuries actively. In addition, for the ready and successful brand of luxuries, how to keep its leading position and how to use the network for publicity and how to keep the customers and explore new and how to avoid weakening of brand image, all these questions are the difficulties in sports luxuries marketing.

\section{Marketing Strategy of China's Sports Luxuries}

\section{To Publicize the Knowledge of Sports Luxuries}

As for the sports luxuries, the consumers shall have the knowledge of appreciation so that they can enjoy the process of consumption, not all the consumers have such professional knowledge, so the implied meaning, expression, message shall be transferred to the customers by different ways, this enables the consumers to rely on the brand after purchase for the first time and the consumers will become loyal purchaser of a certain brand. At the same time, the luxuries Brand Company shall introduce some updated new to the old customers, especially for consumers with fashionable and trendy pursuit and some high-grade consumers.

\section{High Price Embodies the Dignity}

The price of sports luxuries decide its level, the consumers will judge the luxuries by its price, therefore sports luxuries pricing shall meet less people's demand and payable capability. Even so, as per economical theory that the flexibility of sports luxuries income is more than 1 and the change between demand and income is changing in the same direction and the margin for the demand is more than income increment, therefore the market shall not only play a role of attracting the mass but also luxuries can be afforded by the non-high salary people who like to show off.

\section{To Establish the Emotional Bond between Sports Luxuries and Consumers}

Except the single pursuit of sports luxuries, consumers also have the strong brand recognition, china's sports luxuries consumers' recognition is changing, the continues emergency of sports luxuries shall embody and convey consumers' life attitude and integrate consumers' demand and preference into products design, connotation and features so that the core value of products can be displayed and stimulate consumers' desire of purchase.

\section{To Expanding the High-level Customized Group Market}

Presently, sports luxuries is becoming more democracy from the less popular market, however, the value of luxuries show the dignity and taste of different people, the development of china's sports luxuries will become the way of high-end and customized, the consumers will formulate their owner idea of life and outlook on value, so to expanding the high level customized group market is very significant. In the private-customized sports luxuries, consumers will come out from the conspicuous psychology and input self-emotion and creation and by using private-customized sports luxuries to show his taste and attitude of life.

\section{Acknowledgement}

This research was supported by the Humanity and Social Science Youth foundation of 
Ministry of Education of China (No.14YJCZH165), the Natural Science Foundation of Hubei Province (No.2014CFB353) and the Science Research Foundation of Wuhan Business University (No.2015KA009).

\section{References}

[1] Dan Cheng, Chang-bin Chen, An Empirical Study on the Factors Influencing Chinese Consumers' Luxury Consumption Preference, Commercial Research, 5(2014) 134-140.

[2] Xiao-ying Zheng, Si-qing Peng, Shan-shan Dai, Impact of Social Comparison on Conspicuous Consumption: A Psychological Compensation Perspective, Journal of Marketing Science, 10(2014)19-31.

[3] Wei Chen, Expense Research of The University Students Purchasing the Luxury Sports Goods, Journal of Anhui Sports Science, 29(2008)24-25.

[4] Chuan-xin Peng, Research on the Brand Culture of Luxury Goods, China Soft Science, 2(2010)69-77.

[5] Bo-jun Ma, On China's Luxury Production and Consumption-Also on the Ideology of Luxury Production and Consumption in Marx's 'Das Kapital", Journal of Social Sciences, 2( 2013) 32-43.

[6] Lin-yan Feng, Xin-xin Wang, Yun-chun He, The Lastest Development and Enlightenment of Luxury Brands Research, Foreign Economics \& Management, 37(2015)21-31.

[7] Yong-bin Ma, Qi-dong Wang, Ling-li Dong, Cheaper Superiority: How Does Social Exclusion Affect New Luxury Products Consumption, Chinese Journal of Applied Psychology, 20(2014)316-322. 